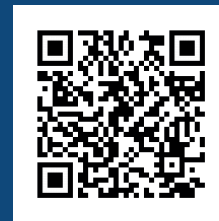

Keywords:

Wood protection

Treatments

Nanostructures

Nanotechnology

Biocides

Received 05/03/2018 Accepted 08/I I/2018

Correspondence: cilene@utfpr.edu.br
Cilene Cristina Borges ${ }^{\text {la }}$, Gustavo Henrique Denzin Tonoli ${ }^{2 a}$, Thiago Moreira Cruz ${ }^{2 b}$, Paulo Junio Duarte ${ }^{2 c}$, Thomaz Antunes Junqueira ${ }^{2 \mathrm{~d}}$

\title{
NANOPARTICLES-BASED WOOD PRESERVATIVES: THE NEXT GENERATION OF WOOD PROTECTION?
}

BORGES, C. C.; TONOLI, G. H. D.; CRUZ, T. M.; DUARTE, P. J.; JUNQUEIRA, T. A. Nanoparticles-based wood preservatives: the next generation of wood protection?. CERNE, v. 24, n. 4, p. 397-407, 2018.

\section{HIGHLIGHTS}

Review on biocides nanoparticles.

Nanoparticles-based wood preservatives.

Nanoparticles biocides applied on wood protection.

Protection against biodeterioration through nanotechnology.

\section{ABSTRACT}

Wood is a natural material that presents a great variation of properties. Many treatments have been developed in order to extend the service life of wood products. Nowadays, products with low toxicity and economic viability are a challenge to researchers. Nanotechnology has been indicated as a solution to this issue, since wood preservatives can be utilized in low concentration, promoting satisfactory results in terms of protection with no color changes. The main goal of this review is to present nanotechnology advances on wood protection. Self-cleaning surfaces, scratch and weathering resistance, and biocides properties have been achieved through nanoparticles (NPs) applications. Studies evaluating the performance of NPs from silver $(\mathrm{Ag})$, boron $(\mathrm{B})$, copper $(\mathrm{Cu})$, zinc $(\mathrm{Zn})$, zinc oxide $(\mathrm{ZnO})$, zinc borate $\left(\mathrm{B}_{2} \mathrm{O}_{6} \mathrm{Zn}_{3}\right)$, and titanium dioxide $(\mathrm{TiO} 2)$ on wood protections have reported promising findings. Tests performed against termites, rot, mold and stain fungi, and UV degradation have demonstrated that some biocides have their properties improved in nanoscale. Controlled release and encapsulation technologies are another important matter once it can increase the effectiveness of wood treatments. NPs risk assessment for human health and the environment are still incipient. Despite of that, some products as nanozinc oxide (nanoZnO) and titanium dioxide (nanoTiO ${ }_{2}$ ) present encouraging potential. $\mathrm{NanoZnO}$ and $\mathrm{NanoTiO}_{2}$ have been reported as promising antifungals, antibacterials, and antiviral agents; beyond theirs biocides properties, low ecotoxicity impacts to the environment are expected. Based on this review, we consider that wood treatments based on NPs may play an important role in the next generation of wood protection systems. 


\section{INTRODUCTION}

Solid wood is a naturally created polymer composite, that results of the combination of cellulose, hemicelluloses and lignin naturally arranged into tubular structures that eventually forms a cylindrically layered composite (Csanády et al., 2015). Wood is a renewable material that has sustainable credentials. According to Food and Agriculture Organization of the United States (FAO, 20l6), greater wood use can make a significant contribution to society's desire for a more sustainable future. Using wood reduces carbon emissions, due to carbon dioxide stored in the timber products. Nowadays, carbon credits are traded as part of a voluntary market in the U.S., while Europe, which ratified the Kyoto Protocol, has a regulated carbon market (Ryan et al., 2010).

Timber has high strength to weight ratio, and is used efficiently in structures where it is carrying a lot of its own self-weight (Ramage et al., 2017). Since the earliest days of human civilization, wood has been a valuable and effective structural material for construction. However, lumber is not naturally durable, and to ensure durability it is necessary to make it resistant through treatments (Canadian Wood Council, 2018). Durability assessment is only based on the tree's heartwood, and not on its sapwood. Due to its extractives, heartwood, has any appreciable degree of durability, while sapwood should be considered perishable.

Nowadays, lumber has been treated with preservatives in order to increase durability. However, there is increasing pressure to be environmentally friendly and to reduce, restrict, or eliminate the use of wood preservatives because of the concern that toxic constituents may leach from the treated wood (Groenier and Lebow, 2006). Conventional wood preservatives such as chromated copper arsenate (CCA), chromated copper borate (CCB), are very effective to protect wood, however cause environmental pollution and some of them are hazardous to animals and human being (Venmalar, 2017). Due to the presence of arsenic, wood treatments based on CCA increase the environmental impacts and have limited commercialization, proving the necessity of development of new products for wood preservation (Santos et al., 20I2).

In Brazil, traditional treatments based on CCA and $C C B$ are the most utilized (Vidal et al., 20I5); even if this kind of treatment causes undesirable wood color changing, and presents risks to environment and human health, they have a significantly higher performance than alternative copper-based preservatives. It has been shown that the percentage of copper removed during leaching tests was higher from wood treated with alternative copper-based preservatives than that of CCA treated wood (Temiz et al., 20/4). For retentions of CCA-C greater than $6.8 \mathrm{Kg} \cdot \mathrm{m}^{-3}$ the expected lifetimes are over 50 years (Jankowsky et al., 20I2). Since increasing life of a wood product implies less work related to replacement and lower cost for the user, this kind of treatment can give a positive environmental contribution because of the extended time of storage of carbon in each wood product, and the longer time to replacements, because every replacement results in an environmental impact (Alfredsen et al., 2017).

However, the Environment Protection Agency (EPA) of United States is reevaluating all chromated arsenical products as part of the Registration Review program (2015) to ensure chemicals can perform their function without adverse effects on human health or environment. CCA has been voluntarily phased out for most uses around residential areas and other areas where human contact with preservative-treated wood is common (Groenier and Lebow, 2006). Thus, the searching for new treatments with efficiency, low toxicity, no danger to human health, and viability of costs production is a challenge for researchers on wood protection.

In this context, nanotechnology advance should be a key for the future of wood protection sciences, since NPs present the possibility of low concentration usage, maintaining the natural color of the wood and controlled releasing of the active ingredient. The main goal of this review is to present advances and possibilities of nanotechnology application on wood protection.

\section{WOOD PROTECTION}

Some species of wood have natural resistance to decomposition caused by microorganisms and insects, however, many of them are scarce or do not grow fast enough to attend the market's demand (Lebow, 20l0). Natural resistance happens due extractives that are substances formed on the tree, and naturally deposited into heartwood. Besides protection, extractives are responsible for the color of the heartwood, the wood part that presents natural durability (Lepage et al., 2017). In general, heartwood from some species is durable (Richardson, 2002), while sapwood from all species is very susceptible to decay (Lepage et al., 2017). Species with darker colored or denser woods are most durable, with high natural resistance. But, indeed, there is no wood that possesses natural resistance to all biodeterioration agents (Richardson, 2002). 
Wood protection is a solution to this impasse. Wood protection science is the process of addiction of toxic or repellent substances called preservatives into wood, in order to increase resistance to decay and durability (Lepage et al., 2017). Preservative treatments can increase wood service life, reducing replacement costs and allowing efficient use of forest resources. Through them, wood products can be protected against several attacks, as decay fungi, harmful insects, or marine borers (Lebow, 20I0).

Regardless of the treatment received, some wood protection requirements have to be attended. To obtain long-term effectiveness, adequate penetration and retention are required for each wood species, chemical preservative, and treatment method. The degree of protection achieved depends on the product used and the proper penetration and retention of the chemicals, according to efficacy and adaptability to the use requirements (Lebow, 20I0).

Leaching also affects the efficacy of the treatment, as well as, the potential impacts on human health and the environment. In the risk assessment of wood preservatives, it is important to know the preservative leaching rates under different exposure scenarios (Waldron et al., 2004).

Considering nanotechnology approaches, the releasing of wood preservatives is another important question. Encapsulation technologies and controlled release methods have revolutionized the use of pesticides and herbicide (Joseph and Morrison, 2006) and may do the same to the wood protection in the near future.

Nowadays, several studies present applications of nanotechnologies on wood protection. In the next sections, they will be properly discussed, looking for high efficiency, low risks to human health, and environmental sustainability.

\section{WOOD PRESERVATIVES}

Structure of cell membranes and DNA (deoxyribonucleic acid) have specific and crucial metal ions; half of that known proteins are predicted to be dependent on metal atoms for their structure and participation in key cellular processes (Waldron and Robinson, 2009; Andreini et al., 2004). In spite of that, these essential metals are lethal to all cells when present in excess, and certain non-essential metal such as $\mathrm{Ag}$, mercury $(\mathrm{Hg})$ and tellurium $(\mathrm{Te})$ are extremely poisonous even at exceptionally low concentrations. Consequently, metals have been used for their antimicrobial properties for thousands of years; they inhibit microbial growth, and kill microorganisms, and their application have also been prized in agriculture, as well as enjoyed a rich history in medicine (Lemire et al., 2013).

In regard to wood protection, several chemicals called preservatives are traditionally used as biocides. Preservatives have fungicide and insecticide action, and can be applied separated or together, according to the service requirements. Preservatives can also be incorporated to coatings to protect against others kinds of deterioration, as light (UV) degradation, for example.

Wood preservatives can be classified according to the solvent, such as oil-based, solvent-based and waterbased preservatives. The main oil-based preservative is creosote, a derived from the distillation of coal tar, with fungicide and insecticide action, that consists of hundreds of compounds and has a variable composition. Solventbased preservatives include naphthenates $(\mathrm{Cu}$ and $\mathrm{Zn}$ ), fire-retardants (borates), copper-8-quinolinolate (oxine copper), tributyltin oxide (TBTO), 3-lodo-2propynyl N-butylcarbamate (IPBC), and isothiazolones (Lepage et al., 2017; Ash and Ash, 2004). Some solventbased preservatives are prohibited in Brazil, like as pentachlorophenol that is a solvent-based preservative widely used as a pressure-treatment to wood in the United States (United States Department of Agriculture - USDA, 2018).

Water-based preservatives include CCA and CCB, alkaline borates, copper azoles B (CA-B), micronized copper azoles (MCA-B and MCA-Q), copper HDO (CXA), and others (Lepage et al., 20I7). Ammoniacal copper zinc arsenate (ACZA), alkaline copper quaternary compounds (ACQ), and copper azoles are also water-based preservatives (CBA-A). Some preservatives are no longer available commercially, as acid copper chromate (ACC), ammoniacal copper arsenate (ACA), ammoniacal copper citrate (CC), and copper dimethyldithiocarbamate (CDDC) (USDA, 2018). Besides these, chromated zinc chloride (CZC), ammoniacal copper zinc arsenate (ACZA), and other several chemicals have been developed to control internal decay, and protect wood against surface degradation (Zabel and Morrel, 20I2).

Insecticides for curative treatments, as pyrethrins and pyrethroids, neonicotinoids, fipronil, and fungicides as carbendazim; products for pretreatment based on carbendazim and cupper oxine; insecticides for plywood's glue line, as cypermethrin and IPBC; and fumigant as Bromomethane (methyl bromide) and phosphine, as well as, biological products, are all used as preservatives (Lepage et al., 2017). 
The evaluation of preservatives performance on wood protection is a slow and expensive process. Fieldtesting experiments of treated wood is the most reliable to evaluate performance with respect to durability and expected service life (Lepage et al., 2017). Unfortunately, the lack of data, the number of involved factors, and how deterioration affects treated performance, make service life prediction very hard and hypothetical (Van de Kuilen, 2007; Brischke et al. 20 I I; Lepage et al., 20 I7).

\section{POTENCIAL OF NANOTECHNOLOGY ON WOOD PROTECTION}

Nanotechnology has been described as the design, characterization, development and application of materials, devices and systems by controlling shape and size at the nanoscale. NPs have multiple applications in medicine, industry and commercial products. (Weir et al., 2008).

Nowadays, an increasing amount of consumer goods contains engineered NPs (Massari et al., 2014). Engineered NPs hold great promise for a variety of industrial and consumer applications, due to their properties (Kaiser et al., 2013a; Resch and Farina, 2015). The paint industry expects that nanomaterials improve ink properties such as water repellence, scratch resistance, durability and antimicrobial properties (Kaiser et al., 2013a). Preparation of self-cleaning surfaces and improvements of properties such as scratch and weathering resistance, have been achieved using NPs, which is also associated with antimicrobial properties of materials (Kandelbauer and Widsten, 2009).

NPs are obtained from a wide variety of materials. The most common of the new generation of NPs are ceramics. They are divided into: (I) metal oxide ceramics such as titanium ( $\mathrm{Ti}), \mathrm{Zn}$, aluminum (Al), and iron (Fe) oxides; and (2) silicate nanoparticles (silicates, or silicon oxides, are also ceramic). Generally, they are in the form of nanoscale flakes (Holister et al., 2003).

Manipulation at the nanometric level can modify properties for new applications in physics, chemistry, biology, and materials science (Resch and Farina, 20I5). The transition from microparticles to NPs can change a number of physical properties, because of the increasing in the ratio of surface area to volume, and the quantum effects of the size particle (Holister et al., 2003). Metallic NPs, as photoactive nanoTiO 2 or nanosilica dioxide (nanoSiO ${ }_{2}$ ), may improve paint properties, such as water repellence, scratch resistance, durability and antimicrobial properties (Kaiser, 20l3a). According to Liu et al. (2002), biocides can be incorporated into several different polymers, copolymers, and polymer blends. Due to the innovation potential, market growth, and the benefits related to NPs, nanotechnologies are considered a strategic area (Resch and Farina, 2015).

Fungicides (tebuconazole, chlorothalonil, and KATHON 930) and one insecticide (chlorpyrifos) incorporated into NPs were reported on wood protection with high biological efficacy for all of them (Liu et al., 2002). Nano wires of vanadium pentoxide were identified as having a potential to be an alternative approach to conventional anti biofouling agents (Natalio et al., 20I2). Results of combination of cooper oxide NPs (nanoCuO) and fluconazole were reported as a potential treatment against fungi on humans (Weitz et al., 20I5).

Performance of wood treated with metallic NPs, based on termite bioassays, was previously reported (Clausen et al., 2009; Kartal et al., 2009; and Mantanis et al., 20I4). Treatments performed in southern yellow pine (SYP) with nanoZnO of 30 and $70 \mathrm{~nm}$ diluted in water (I.0, 2.5 and 5.0\%) presented less than $4 \%$ of wood consumption, and caused 94 to $99 \%$ of termite mortality after 25 to 27 days incubation. In contrast, termites consumed 10 to $12 \%$ of the blocks treated with with zinc sulfate $\left(\mathrm{ZnSO}_{4}\right)$, and termite mortality was considerably lower for all three $\mathrm{ZnSO}_{4}$ treatment concentrations, I.0, 2.5 and 5.0\% (Clausen et al., 2009). Lower termite mortality in $\mathrm{ZnSO} 4$ treated wood compared to nano $\mathrm{ZnO}$ may be due to differences in bioactivity that results from changes in the chemical structures (Serine et al., 2009). Particles of boron (nanoB) of $30 \mathrm{~nm}$ (1\%) and boric acid $\left(\mathrm{H}_{3} \mathrm{BO}_{3}\right)$ control at $1 \%$ caused $100 \%$ of termite mortality in SYP, while NanoZn (30 nm) with surfactant (I\%) caused moderate termite mortality (3I\%), and $\mathrm{ZnSO}_{4}$ at $1 \%$ resulted in low mortality rates of $1-7 \%$ (Kartal et al., 2009). Treatments with particles of $80 \mathrm{~nm}$ (2\%) of nanozinc borate $\left(\mathrm{B}_{2} \mathrm{O}_{6} \mathrm{Zn}_{3}\right)$ and nanozinc borate plus water-borne acrylic polymer emulsion caused $100 \%$ termite mortality in black pine treated wood (Pinus nigra L.), with a considerably low mass losses, i.e. $3.3 \%$ and $2.3 \%$, respectively. NanoZnO (80nm, at $2 \%)$ formulations caused low mortalities at 9-10\%, while suffered significantly low mass losses at 4-7\% (Mantanis et al., 2014). NanoCuO provides no protection to termites (Kartal et al., 2009; Mantanis et al., 20I4).

Attempts of mold growth control using metal NPs were reported in literature by several authors (Kartal et al., 2009; Clausen et al., 2009; Mantanis et al., 20I4). Against mould growth, nanometals preparations of $30 \mathrm{~nm}(\mathrm{Cu}, \mathrm{Zn}$ or $\mathrm{B}$ at $1 \%$ ) and respective controls (cooper sulfate (CuSO4), $\mathrm{ZnSO}_{4}$, and $\mathrm{H}_{3} \mathrm{BO}_{3}$ at (I\%) and untreated) failed to provide adequate protection to wood (Kartal et al., 2009). However, results of Mantanis et al. 
(2014) demonstrate a slightly inhibition of mold fungi by nanozinc borate of $80 \mathrm{~nm}(2 \%)$. At high concentration, NanoZnO treatments (30 and $70 \mathrm{~nm}$, at $5 \%$ ) resulted in moderate inhibition ( 20 - 32\%) of mold and sapstain growth (Clausen et al., 2009). Concerning to nanosilver (nanoAg), it was reported the protective effect against mold, blue stain fungi and algae was insufficient for coatings (Künniger et al., 20l3).

NPs $(30 \mathrm{~nm})$ of $\mathrm{Cu}, \mathrm{Zn}$ and $\mathrm{B}$ at $\mathrm{I} \%$ inhibited the white-rot test fungus Trametes versicolor (Kartal et al., 2009). The same white-rot fungi (Trametes versicolor) was significantly inhibited by nanoZn-based preparations in different treatments and concentrations (Clausen et al., 2009; Kartal et al., 2009; Mantanis et al., 20l4). Nanozinc borate (80 nm, at $2 \%$ ) plus acrylic emulsion imparted very high resistance in pine wood to the whiterot fungus (Mantanis et al., 20l4).

Prevention of decay caused by Hypocrea lixii (white-rot) and Mucor circinelloides (brown-rot) were reported in Pinus Sylvestris L., Abies alba M., Junglas regia L., Castanea sativa M., Prunus avium L., Quercus petrea L., Fagus sylvatica L., and Fraxinus excelsior L., independently of wood species and fungus type, through photo-catalytic activity of $\mathrm{NanoTiO}_{2}$. In that work, $\mathrm{TiO}_{2}$ impregnation was performed by immersion of untreated samples for seven days in a solution of $\mathrm{TiO}_{2} \mathrm{NPs}(0.25 \mathrm{mg} / \mathrm{mL})$ and $0.01 \mathrm{~mL}$ of surfactant (De Filpo et al., 2013).

NanoZnO (30 and $70 \mathrm{~nm}$ ) did not significantly inhibit brown-rot fungi Postia placenta (2.5 or 5.0\%) or Antrodia sp. (I.0\%). At $5.0 \%$, nano $\mathrm{ZnO}$ caused $74 \%$ lower mass losses than in the untreated control in Gloeophyllum trabeum attack (Clausen et al., 2009). Copper-treated (30 nm, at 1\%) specimens exposed to Antrodia sp. showed high mass losses (19 - 33\%). However, mass loss of treated wood exposed to $G$. trabeum was greatly reduced $(65 \%)$ with nanoCu (I\%) or $\mathrm{CuSO}_{4}(3-15 \%)$, compared with untreated controls (Kartal et al., 2009). SYP treated with KATHON 930 in polyvinylpyridine, at levels of $0.1 \mathrm{Kg}$ of biocide/ $\mathrm{m}^{3}$, presented weight loss of only $5 \%$ after 50 days of exposure to G. trabeum (Liu et al., 2002). NanoZnO (80 $\mathrm{nm}$, at $2 \%)$ and nanozinc borate treatments $(80 \mathrm{~nm}$, at $2 \%$ ) did not inhibited the brown-rot fungus Tyromyces palustris (Mantanis et al., 20l4). Treatments results of basic copper carbonate $\mathrm{NPs}\left(\mathrm{CuCO}_{3} \cdot \mathrm{Cu}(\mathrm{OH})_{2}\right)$ against the brown rot fungus Rhodonia placenta also do not support increasing antifungal efficacy due to nanosizing effects (Civardi et al., 20I5a).

NanoZnO particles $(30 \mathrm{~nm})$ were reported on wood weatherability control. Graying was significantly reduced by nano $\mathrm{ZnO}$ treatments at high concentration
(5\%), but it was not completely eliminated (Clausen et al., 20I0). It happens because $\mathrm{ZnO}$ is a highly effective UV protector, due its strong ultraviolet absorption (Yu et al., 20I0). Water repellency on wood surfaces persisted for 8 weeks. After 12 months of weathering, specimens treated with $1 \%$ nanoZn presented approximately $10 \%$ of reduction in $24 \mathrm{~h}$ water absorption, while specimens treated with 2.5 and $5.0 \%$ nanoZn showed $32 \%$ reduction in $24 \mathrm{~h}$ water absorption, when compared to untreated samples (Clausen et al., 20l0). The Water absorption changes founded are an important result because in imply in a decreasing of equilibrium moisture content of the wood; It is known that in moisture contents below the fiber saturation point natural resistance of wood to insects and fungi increase (Lepage et al., 2017).

Authors concluded that nanoZnO has desirable wood protection properties, such as leach resistance, UV protection, and termite resistance, even it would provide no adequate protection against decay or mold (Clausen et al., 2009).

In general, nanotechnologies have the potential to affect all wood preservation field through the development of new preservatives with low toxicity and high effectiveness. Nanotechnologies also can affect wood protection on several parameters as penetration, retention, and leaching. The next sections will discuss it.

\section{PENETRATION OF NPS IN THE WOOD}

According to Freeman and Mclntyre (2008), the size of metal particles may affect penetration of the wood cell walls and reactions with wood molecular constituents. The degree of penetration and uniformity of distribution of particles into wood cellular structure is inversely related to the prevalence of large size particles.

Large particles may obstruct tracheids and inhibit the preservative penetration. On the other hand, complete penetration and uniform distribution of preservative in wood is expected if the particle size of the preservative is smaller than the diameter of the window pit $(10 \mathrm{~nm})$ or membrane openings in a bordered pit (400 - $600 \mathrm{~nm})$. In concern to hardwoods, wood pore diameters are measured in micrometers. A Diameter of $50 \mu \mathrm{m}$ is considered a relatively small pore size (Maier, 2018) however it is greater than bordered pit of softwoods.

NPs are created with controlled particle size and some of them demonstrated high dispersion stability (Freeman and Mclntyre, 2008), being this an important feature, since particles-size in the range of $1-100 \mathrm{~nm}$ may improve penetrability of chemical reagents into the 
wood (Freeman and Mclntyre, 2008; Kartal et al., 2009). Nanometal preparations have low viscosity and a surfactant addition can further increase dispersion stability by enabling liquid dispersion of higher concentrations of nanometal particles (Kartal et al., 2009; Lykidis et al., 2013). Information about nanoTiO 2 penetration into the microscopic pores of wood are poorly reported. NPs penetration depth can be estimate by SEM analysis. It was described as a thin homogeneous layer of $\mathrm{TiO}_{2} \mathrm{NPs}$, with an average size of $50 \mathrm{~nm}$ covering wood internal structures, without changing natural appearance (De Filpo et al., 2013).

Regarding to wood protection requirements, nanometals show potential for great penetration and protection, with a more uniform particulate distribution over a wood surface.

\section{CHEMICAL RETENTION IN THE WOOD}

Retention is the amount of preservative that is retained in the sapwood after a treatment cycle. It is one measurement of the degree of protection provided by a treatment, been usually expressed as kilograms of preservative per cubic meter of wood (Canadian Wood Council, 2018). Specimen size and configuration cause differences in chemical retention (Kartal et al., 2009; Mantanis et al., 2014). Thin specimens had higher retention than large ones (Kartal et al., 2009).

Comparing NPs with microparticles, there was no difference between nanoB and $\mathrm{H}_{3} \mathrm{BO}_{3}$ chemical retentions, however, chemical retention of $\mathrm{NanoCu}$ was $30 \%$ less than $\mathrm{CuSO}_{4}$. For nanoZn preparations $(30 \mathrm{~nm}$, without surfactant) and $\mathrm{ZnSO}_{4}$, retentions were similar (Kartal et al., 2009). Otherwise, nano $\mathrm{ZnO}$ as aqueous dispersions (with $30 \mathrm{~nm}$ and $70 \mathrm{~nm}$ average diameters) presented higher chemical retentions than $\mathrm{ZnSO}_{4}$ treated wood, for the same concentration (Clausen et al., 20 I I).

Surfactants affect chemical retention (Kartal et al., 2009; Mantanis et al., 20l4). With surfactant, retentions were $30 \%$ and $16 \%$ lower than $\mathrm{ZnSO}_{4}$, for nanoZn and nanoZn with Ag, respectively (Kartal et al., 2009), and the highest retention levels in treatments with nano $\mathrm{ZnO}$ were obtained without acrylic emulsion (Mantanis et al., 20I4).

Due to differences that specimen sizes, emulsions and emulsifying agents cause to chemical retention of wood preservatives, it is hard to compare reported results. However, great development can be achieved by exploring these features.

\section{CHEMICAL LEACHING OF THE NPS}

Wood preservatives have to present ability to fixate inside wood. This parameter is usually expressed through leaching rates. Leaching is greatest in treatments with high retention levels and high exposed surface area. The highest rates of leaching occurs within the first months of service, and it is increased by exposing the wood to water flow, low $\mathrm{pH}$, and water-soluble organic acids (Lebow, 1996).

Information provided over depletion of chemical retention of nano $\mathrm{ZnO}(30 \mathrm{~nm})$ on wood weathered specimens ( 12 months of outdoor exposure) suggested specimens vacuum treated with $1 \%$ of nano $\mathrm{ZnO}$ were leach resistant, while $\mathrm{ZnSO}_{4}$ readily leached (Clausen et al., 2010). It happens because $\mathrm{ZnSO}_{4}$ leached faster than nanoZn (Kartal et al., 2009). NanoZnO retention in specimens treated with $1 \%$ nano $\mathrm{ZnO}$ presented no changes, but specimens treated with 2.5 and $5.0 \%$ nanoZnO showed 65 and $58 \%$ of nanoZnO loss, respectively (Clausen et al., 2010).

Leaching from wood treated with nanoCu $(30$ $\mathrm{nm}$ particle diameter) was barely detectable, but the rate of leaching for $\mathrm{CuSO}_{4}$ was faster. On the same way, nano preparations of $\mathrm{Zn}$ and $\mathrm{Zn}$ with $\mathrm{Ag}$ showed lower leaching than $\mathrm{ZnSO}_{4}$ (Kartal et al., 2009). NanoB presented very low leaching resistance (Mantanis et al., 20I4; Lykidis et al., 20I3; Kartal et al., 2009). Van der Waals forces and changes in charge can explain the low leaching of nanometals (Kartal et al., 2009; Clausen et al., 2009; Clausen et al. 2010).

$\mathrm{NanoCuO}$ treated specimens with and without emulsion showed low percentage of leaching (Mantanis et al., 2014; Clausen et al., 2009). Specimens treated with nanoCu, with and without surfactant, had high leaching resistance compared to the control $\mathrm{CuSO}_{4}$. NanoZn and nanoZn plus $\mathrm{Ag}$, both with surfactant, had low percentage of leaching ( $9 \%$ and $8 \%$, respectively), when compared to $\mathrm{Zn}$ preparations without surfactant (31\% and 33\%), and $\mathrm{ZnSO}_{4}$ (84\%) (Kartal et al., 2009). Preparations of nano $\mathrm{ZnO}$ and zinc borate plus acrylic emulsion had a lower percentage of leaching than the same zinc preparations without emulsion. However, nanoCuO treated specimens without emulsion had the lowest percentage of leaching (7.5\%), while nanCuO with emulsions had high percentage of leaching, I $3 \%$ and 29\%, respectively (Mantanis et al., 2014). It happens because addition of a water-borne acrylic emulsion binder in the compound may increase its affinity to wood polymers and subsequently decrease leaching (Lykidis et al., 20I3).

It is possible to affirm that leaching can be controlled by using emulsions and surfactants (Kartal et al., 2009; Lykidis et al., 20I3; Mantanis et al., 20I4), but this affirmation has to be more explored in future researches, looking for improved results. 


\section{CONTROL OF RELEASING OF BIOCIDES}

In order to control releasing, extend wood preservatives activity, and reduce their toxic effects, biocides NPs could be encapsulated. Encapsulation provides controlled means of prolonging biocidal activity, protecting against biocide leaching, UV-induced degradation, and consequently increasing lifetime effects (Sørensen et al., 20I0). Besides, external conditions such as the $\mathrm{pH}$, can be used for a controlled releasing when they reach specific required conditions (Pérez-de-Luque and Rubiales, 2009).

Controlled release of chemical substances can be evaluated by using different approaches. The surface assembly of polyelectrolyte multilayers on the microcapsule surface is a very promising tool for controlling the release of hydrophobic actives (Trojer et al., 2015).

Studies demonstrated the effectiveness of an environmentally friendly sustained releasing system of fipronil insecticide into silica nanocapsules against subterranean termites in laboratory tests (Wibowo et al., 2014). Polymeric capsules containing biocides improved the resistance of birch wood to white-rot attack, with a very low biocide loading required $\left(0.1\right.$ to $\left.0.8 \mathrm{Kg} \cdot \mathrm{m}^{-3}\right)$. In general, nature-derived material, as carbon nanotubes, polymers, mesoporous alumina and mesoporous/hollow silica present high potential for controlled release systems, according to several authors (Mattos et al., 20l7).

Even if studies about NPs control of releasing are still incipient, they are very promisors because they could increase effectiveness of wood preservatives, and consequently decrease costs of maintenance and replacement of wood products.

\section{HUMAN AND ENVIRONMENTAL RISKS OF NPS}

The increasing usage of engineered NPs intensify the probability of consumer and workers to get into contact with materials that might cause adverse health effects (Oberdorster et al., 2005; Silva et al., 2010). Despite this, there are few information about NPs safety.

The exponential developments of nanotechnologies contrast to concerns of public health, due to the insufficient risk assessment to environment and human health (Louro et al., 20I3). Both beneficial (e.g. photocatalytic activity and water repellence) or harmful effects (e.g. induction of oxidative stress and cellular dysfunction) can be exerted by the desired properties of engineered NPs (Stoeger et al., 2009).

Künniger et al. (20/3), studying functionality and environmental impacts of metallic NPs of $\mathrm{Ag}$, found the total $\mathrm{Ag}$ released from products with nanoAg was proportional to the overall erosion of the coating, and there was indication that metallic nanoAg are transformed to $\mathrm{Ag}$ complexes less toxic than ionic $\mathrm{Ag}$. NanoCu-based wood treatments may end up dispersed into the environment being inhaled, causing harm, and become a human health potential risk (Civardi et al., $20 I 5 b)$. It is advocated to intensify studies focused at a complete characterization of its toxicity and behavior in environmentally exposure (Anjum et al., 20I5).

$\mathrm{NPs}$ of $\mathrm{TiO}_{2}$ may undergo to physicochemical transformation during incineration, requiring further research to identify what NPs will be emitted to the environment from incinerated material (Massari et al., 2014). Engineered NPs from Ag had higher ecotoxic impact than those from $\mathrm{TiO}_{2}$, with a linear regression between $\mathrm{Ag}$ content in products and the potential ecotoxicity impacts to environment (Miseljic and Olsen, 20I4). Kaiser et al. (20I3b), working about engineered NPs used at paint industry showed that neither the gastrointestinal cells nor immune system cells were significantly affected when exposed to nanoTiO $\mathrm{Ti}_{2}$ and nanoSiO $\mathrm{S}_{2}$, while several cell parameters were affected when exposed to nanoAg. Future research aiming at unveiling the destination of nano $\mathrm{Ag}$ particles, its transformation, accumulation, and toxicity potential, as well as their impact on environmental and human health are recommended (Anjum et al., 20l3).

$\mathrm{NanoZnO}$ has been indicated as a promising antibacterial, antifungal, and antiviral agent (Beegam et al., 2016) with promising results in the control of several kinds of cancer cells (Rasmussen et al., 2010; Wahab et al., 20I3a; Wahab et al., 20I3b; Selvakumari et al., 20I5; Vinardell and Mitjans, 2015; Namvar et al., 20I5; Bisht and Rayamajhi, 2016). Studies have also shown potential beneficial environment effects of nanoZnO (Beegam et al., 2016), but in order to understand their potential risk, a comprehensive material life cycle analysis is necessary (Bystrzejewska-Piotrowska et al., 2009; Oliveira et al., 20I2; Silva et al., 20I2a; Silva et al., 20I2b).

Due to the increasing concern of NPs security, there is a deceleration in nanotechnology research, in the field of medical and food industries, because of the fact that researchers have found that NPs could diffuse into the human body and cause adverse effects. Considering the increasing of production and application of nanomaterials, as well as, the related consumer products, it was suggest that a testing strategy for different kinds of NPs have to be established (Hougaard et al., 20I5). Society might overestimate the short-term effects of nanotechnologies, while underestimating the long- 
term effects (Bystrzejewska-Piotrowska et al., 2009). Despite this, many authors regard nanotechnology as the base for the next industrial revolution (Resch and Farina, 2015).

\section{PROSPECTS AND CONSIDERATIONS ON WOOD PROTECTION}

There are many possibilities of nanotechnologies applications on wood protection. Nanometals-based treatments present good perspective to control water repellence, scratch resistance, durability, self-cleaning surfaces, wood biodegradation, and also can improve weathering resistance.

White-rot fungi inhibition and termites control by using NPs were reported; but no nanometal preparation were effective against brown-rot fungi - Meruliporia incrassate, Gloeophyllum trabeum and Tyromyces palustris. However, control over decay caused by Mucor circinelloides were reported.

Authors reported information about chemical retention and leaching of NPs and weathering protection through NPs, with good results. No significant differences between different NPs sizes were reported for leach resistance and termites. However, some NPs can be considered as friendly biocides with potential application on wood protection industrial process in the future, as nano $\mathrm{ZnO}$ and nano $\mathrm{TiO}_{2}$.

NPs-based wood preservatives have to be properly explored in future researches, focusing on the most promising results reported, as well as, other chemical substances with biocides activity, exploring the nanotechnology open issues. It is necessary to keep in mind that there are not sufficient risk assessment for human health and the environment impacts of NPs yet. However, although there is no answer to all questions, based on this review, it can be considered that NPs-based treatments may perform an important role on the next generation of wood protection.

\section{REFERENCES}

ALFREDSEN, G.; BRISCHKE, C.; MEYER-VELTRUP, L.; HUMAR, M.; FLAETE, P. O. The effect of different test methods on durability classification of modified wood. Pro Ligno, v. I3, n. 4, p. 290-297, 2017.

ANDREINI, C.; BERTINNI, I.; ROSATO, A. A hint to search for metalloproteins in gene banks. Bioinformatics, v. 20, n. 9, p. 1373-I380, 2004.

ANJUM, N. A.; GILL, S.; DUARTE, A.; PEREIRA, E.; AHMAD, I. Silver nanoparticles in soil-plant systems. Journal of Nanoparticle Research, vI5. n. 9, p. I-26, 2013.
ANJUM, N. A.; DUARTE, A. C.; PEREIRA, E.; IQBAL, M.; LUKATKIN, A. S.; AHMAD, I. Nanoscale copper in the soil plant system - toxicity and underlying potential mechanisms. Environmental Research, v. 138, p. 306-325, 2015.

ASH, M.; ASH, I. Handbook of preservatives. Synapse Information Resources, Inc., 2004. 850p.

BEEGAM, A.; PRASAD, P.; JOSE, J.; OLIVEIRA, M.; COSTA, F. G.; SOARES, A. M. V. M.; GONÇALVES, P. P.; TRINDADE, T.; KALARIKKAL, N.; THOMAS, S.; PEREIRA, M. L. Environmental Fate of Zinc Oxide Nanoparticles: Risks and Benefits. In: SOLONESKI, S. AND LARRAMENDY, M.L. Toxicology - New Aspects to This Scientific Conundrum. IntechOpen, 2016. p. 8I-II2.

BISHT, G.; RAYAMAJHI, S. ZnO nanoparticles: a promising anticancer agent. Nanobiomedicine, v.9, p. I-I I, 2016.

BRISCHKE, C.; WELZBACHER, C. R.; MEYER, L.; BORNEMANN, T.; LARSSON-BRELID, P.; PILGÅRD, A.; FRÜHWALD-HANSSON, E.; WESTIN, M.; RAPP, A. O.; THELANDERSSON, S.; JERMER, J. (INTERNATIONAL RESEARCH GROUP ON WOOD PROTECTION - IRG/ WP). Service life prediction of wooden componentsPart 3: Approaching a comprehensive test methodology. Available at: https:/www.sp.se/sv/index/ research/woodbuild/publications/Documents/IRG\%20 I I 20464.pdf. Accessed in: 22 October 2018.

BYSTRZEJEWSKA-PIOTROWSKA, G.; GOLIMOWSKI, J.; URBAN, P. L. Nanoparticles: Their potential toxicity, waste and environmental management. Waste Management, v. 29, n. 9, p. 2587-2595, 2009.

CANADIAN WOOD COUNCIL. Durability Solutions. Available at: http://cwc.ca/design-with-wood/ durability/durability-solutions/. Accessed in: 10 April 2017.

CIVARDI, C.; SCHUBERT, M.; FEY, A.; WICK, P. SCHWARZE, F. W. M. R. Micronized Copper Wood Preservatives: Efficacy of Ion, Nano, and Bulk Copper against the Brown Rot Fungus Rhodonia placenta. PloS one, v. I0, n. II, p. I-I5, 20I5a.

CIVARDI, C.; SCHWARZE, F. W. M. R.; WICK, P. Micronized copper wood preservatives: An efficiency and potential health risk assessment for copper-based nanoparticles. Environmental Pollution, v. 200, p. 126-132, 20I5b.

CLAUSEN, C. A.; YANG, V. W.; ARANGO, R. A.; GREEN III, F. (AMERICAN WOOD PROTECTION ASSOCIATION - AWPA) Feasibility of Nanozinc Oxide as a Wood Preservative. Available at: https://www.fpl.fs.fed. us/documnts/pdf2009/fpl_2009_clausen00I.pdf. Accessed in: 22 January 2016.

CLAUSEN, C. A.; GREEN III, F.; KARTAL, S. N. Weatherability and Leach Resistance of Wood Impregnated with NanoZinc Oxide. Nanoscale Research Letters, v. 5, n. 9, p. I464-I467, 2010. 
CLAUSEN, C. A.; YANG, V. W.; ARANGO, R. A.; GREEN III, F. The role of particle size of particulate nano-zinc oxide wood preservatives on termite mortality and leach resistance. Nanoscale Research Letters, v. 6, n. I, p. 427, 20 I I.

CSANÁDY, E.; MAGOSS, E.; TOLVAJ, L. Wood Surface Stability. In: CSANÁDY, E.; MAGOSS, E.; TOLVAJ, L. Quality of Machined Wood Surfaces. Springer International Publishing Switzerland, 20I5. P. I3-I08.

DE FILPO, G.; PALERMO, A. M.; RACHIELE, F.; NICOLETTA, F. P. Preventing fungal growth in wood by titanium dioxide nanoparticles. International Biodeterioration \& Biodegradation, v. 85, p. 217-222, 2013.

FREEMAN, M. H.; MCINTYRE, C. R. A comprehensive review of copper-based wood preservatives: with a focus on new micronized or dispersed copper systems (Report). Forest Products Journal, v. 58, n. II, p. 6, 2008.

FOOD AND AGRICULTURE ORGANIZATION (FAO). Forestry for a low-carbon future Integrating forests and wood products in climate change strategies. Available at: http:// www.fao.org/3/a-i5857e.pdf. Accessed in: 23 January 2018.

GROENIER, J. S.; LEBOW, S. Preservative-treated wood and alternative products in the Forest Service. US Dept. of Agriculture, Forest Service, Technology \& Development Program. Missoula, MT, 2006. 44 p.

HOUGAARD, K. S.; CAMPAGNOLO, L.; CHAVATTE-PALMER, P.; TARRADE, A.; ROUSSEAU-RALLIARD, D.; VALENTINO, S.; PARK, M. V.; DE JONG, W. H.; WOLTERINK, G.; PIERSMA, A. H.; ROSS, B. L.; HUTCHISON, G. R.; HANSEN, J. S.; VOGEL, U.; JACKSON, P.; SLAMA, R.; PIETROIUSTI, A.; CASSEE. F. R. A perspective on the developmental toxicity of inhaled nanoparticles. Reproductive Toxicology, v. 15, n.56, p. I I8-40, 2015.

HOLISTER, P.; WEENER, J. W.; ROMAN VAS, C.; HARPER, T. (NANOPARTICLES. TECHNOLOGY WHITE PAPER). Available at: http://www.nanoparticles.org/pdf/ Cientifica-WP3.pdf. Accessed in: 20 December 2015.

JANKOWSKY, I. P.; LEPAGE, E. S.; SALVELA, C.; VIDAL, J. M.; TAKESHITA, S. (THE INTERNATIONAL RESEARCH GROUP ON WOOD PROTECTION - IRG/WP and INTERNATIONAL UNION OF FOREST RESEARCH ORGANIZATIONS - IUFRO - IRG IUFRO DOCUMENTS). Effectiveness of CCA-C and CCB preservatives after a 30 years stake test. Available at: https:// www.iufro.org/download/file/9126/5289/50300-estoril I 2irg-iufro-sessions_pdf/. Accessed in : I5 February 2016.

JOSEPH, T.; MORRISON, M. (EUROPEAN NANOTECHNOLOGY GATEWAY). Nanotechnology in Agriculture and Food. Available at: https://www. nanowerk.com/nanotechnology/reports/reportpdf/ report6I.pdf. Accessed in: 17 February 2016.

KAISER, J. P.; ZUIN, S.; WICK, P. Is nanotechnology revolutionizing the paint and lacquer industry? A critical opinion. Science of the Total Environment, v. 442, p. 282-289, 20I3a.
KAISER, J. P.; ROESSLEIN, M.; DIENER, L.; WICK, P. Human health risk of ingested nanoparticles that are added as multifunctional agents to paints: an in vitro study. PLoS One, San Francisco, v. 8, n. 12, p. I-II, 20I3b.

KANDELBAUER, A.; WIDSTEN, P. Antibacterial melamine resin surfaces for wood-based furniture and flooring. Progress in Organic Coatings, v. 65, n. 3, p. 305-313, 2009.

KARTAL, S. N.; GREEN, F; CLAUSEN, C. A. Do the unique properties of nanometals affect leachability or efficacy against fungi and termites? International Biodeterioration \& Biodegradation, v. 63, n. 4, p. 490-495, 2009.

KIM, S. Directed Molecular self-assembly: its applications to potential electronic materials. Electronic Materials Letters, v. 3, n.3, p. 109-1 |4, 2007.

KÜNNIGER, T.; GERECKE, A. C.; ULRICH, A.; HUCH, A.; VONBANK, R.; HEEB, M.; WICHSER, A.; HAAG, R.; KUNZ, P.; FALLER, M. Release and environmental impact of silver nanoparticles and conventional organic biocides from coated wooden façades. Environmental Pollution, v. I84, p. 464-47I, 2013.

LEBOW, S. T. (UNITED STATES DEPARTMENT OF AGRICULTURE, FOREST SERVICE, FOREST PRODUCTS LABORATORY) Leaching of Wood Preservative Components and Their Mobility in the Environment Summary of Pertinent Literature. General Technical Report. Madison, WI, 1996. 36 p.

LEBOW, S. T. Wood Preservation. United States Department of Agriculture, Forest Service, Forest Products Laboratory. In: U. S. DEPT. OF AGRICULTURE, FOREST SERVICE, and FOREST PRODUCTS LABORATORY. Wood Handbook: Wood as an Engineering Material. Madison, WI, 20l0. p. 328-355.

LEMIRE, J. A.; HARRISON, J. J.; TURNER, R. J. Antimicrobial activity of metals: mechanisms, molecular targets and applications (Report). Nature Reviews Microbiology, v. II, n. 6, p. 37I-384, 2013.

LEPAGE, E.; SALIS, A. G. de; GUEDES, E. C. R. Tecnologia de proteção da madeira. I ed., Montana Química S. A, 2017.225 p.

LIU, Y.; LAKS, P.; HEIDEN, P. Controlled release of biocides in solid wood. II. Efficacy against Trametes versicolor and Gloeophyllum trabeum wood decay fungi. Journal of Applied Polymer Science, v. 86, n. 3, p. 608-6I4, 2002.

LOURO, H.; BORGES, T.; SILVA, M. J. Nanomateriais manufaturados: novos desafios para a saúde pública. Revista Portuguesa de Saúde Pública, v. 3I, n. 2, p. I88-200, 2013.

LYKIDIS, C., MANTANIS, G., ADAMOPOULOS, S., KALAFATA, K., ARABATZIS, I. Effects of nano-sized zinc oxide and zinc borate impregnation on brown rot resistance of black pine (Pinus nigra L.) wood. Wood Material Science \& Engineering,v. 8, n. 4, p. 242-244. 2013. 
MAIER, E. (THE WOOD DATABASE). Hardwood Anatomy. Available at: https://www.wood-database.com/woodarticles/hardwood-anatomy/. Accessed in: 23 October 2018.

MANTANIS, G.; TERZI, E.; KARTAL, N.; PAPADOPOULOS, A. N. Evaluation of mold, decay and termite resistance of pine wood treated with zinc- and copper-based nanocompounds. International Biodeterioration \& Biodegradation, v. 90, p. I40-I44, 2014.

MASSARI, A.; BEGGIO, M.; HREGLICH, S.; MARIN, R.; ZUIN, $S$. Behavior of $\mathrm{TiO}_{2}$ nanoparticles during incineration of solid paint waste: A lab-scale test. Waste Management, v. 34, n. I0, p. I897-1907, 2014.

MATTOS, B. D.; TARDYB, B. L.; MAGALHÃES, W. L. E.; ROJAS. O. J. Controlled release for crop and wood protection: Recent progress toward sustainable and safe nanostructured biocidal systems. Journal of Controlled Release, v. 262, p. 139-150, 2017.

MISELJIC, M.; OLSEN, S. Life-cycle assessment of engineered nanomaterials: a literature review of assessment status. Journal of Nanoparticle Research, v. I6, n. 6, p. I-3, 20 I4.

NAMVAR, F;; RAHMAN, H. S.; MOHAMAD, R.; AZIZI, S.; TAHIR, P. M.; CHARTRAND, M. S.; YEAP, S. K. Cytotoxic effects of biosynthesized zinc oxide nanoparticles on murine cell lines. Hindawi Publishing Corporation - EvidenceBased Complementary and Alternative Medicine., v. 20I5, p.I-II, 2015.

NATALIO, F; ANDRÉ, R.; HARTOG, A. F; STOLL, B.; JOCHUM, K. P.; WEVER, R.; TREMEL, W. Vanadium pentoxide nanoparticles mimic vanadium haloperoxidases and thwart biofilm formation. Nature Nanotechnology, v. 7, n. 8, p. 530-535, 2012.

OBERDORSTER, G.; OBERDORSTER, E.; OBERDORSTER, J. Nanotoxicology: an emerging discipline evolving from studies of ultrafine particles. Environmental Health Perspectives, v. I I3, n.7 p. 823-839, 2005.

OLIVEIRA, M. L. S.; WARD, C. R.; IZQUIERDO, M.; SAMPAIO, C. H.; DE BRUM, I. A. S., KAUTZMANN, R. M., SABEDOT, S.; QUEROL, X.; SILVA, L. F. O. Chemical composition and minerals in pyrite ash of an abandoned sulphuric acid production plant. Science of the Total Environment, v. 430, p. 34-47, 2012.

PÉREZ-DE-LUQUE, A.; RUBIALES, D. Nanotechnology for parasitic plant control. Pest Management Science, v. 65, n. 5, p. 540-545, 2009.

RYAN, M. G.; HARMON, M. E.; BIRDSEY, R. A.; GIARDINA, C. P.; HEATH, L. S.; HOUGHTON, R. A.; JACKSON, R. B.; MCKINLEY, D. C.; MORRISON, J. F.; MURRAY, B. C.; DIANE, E.; PATAKI, D. E.; SKOG, K. E.( ECOLOGICAL SOCIETY OF AMERICA) Issues in ecology - A Synthesis of the Science on Forests and Carbon for U.S. Forests. Available at: https://www.fs.fed.us/rm/ pubs_other/rmrs_2010_ryan_m002.pdf. Accessed in: 22 January 2017.
RAMAGE, M. H.; BURRIDGE, $H_{.}$; BUSSE-WICHER, M.; FEREDAY, G.; REYNOLDS, T.; SHAH, D. U.; WU, G.; YU, L.; FLEMING, P.; DENSLEY-TINGLEY, D.; ALLWOOD, J.; DUPREE, P.; LINDEN, P. F; SCHERMAN, O. The wood from the trees: The use of timber in construction. Renewable and Sustainable Energy Reviews, v. 68, p. 333-359, 2017.

RASMUSSEN, J. W.; MARTINEZ, E.; LOUKA, P.; WINGETT. D. $G$. Zinc oxide nanoparticles for selective destruction of tumor cells and potential for drug delivery applications. Expert Opinion on Drug Delivery, v.7, n.9, p. 1063-1077, 2010.

RESCH, S.; FARINA, M. C. Knowledge map in nanotechnology in the food and agriculture sector. Revista de Administração da Mackenzie, v. 16, n. 3, p. 5I-75, 2015.

RICHARDSON, B. A. Wood Preservation. 2.ed. London: E \& FN SPON, 2002. 240p.

SANTOS, P. S. B.; GARCÍA, A.; CADEMARTORI, P. H. G.; GATTO, D. A.; LABIDI, J. (THE INTERNATIONAL RESEARCH GROUP ON WOOD PROTECTION IRG/WP and INTERNATIONAL UNION OF FOREST RESEARCH ORGANIZATIONS - IUFRO - IRG IUFRO DOCUMENTS). Study of the use of organosolv lignin as bio-preservative of wood. Available at: https://www. iufro.org/download/file/9 | 26/5289/50300-estoril I 2-irgiufro-sessions_pdf/. Accessed in: 22 May 2018.

SERINE, N.; ASHITANI, T.; MURAYAMA, T.; SHIBUTANI, S.; HATTORI, S.; TAKAHASHI, K. Bioactivity of latifolin and its derivatives against termites and fungi. Journal of Agricultural and Food Chemistry, v. 57, p. 5707-57 I2, 2009.

SELVAKUMARI, D. R.; MAHALAKSHMI, V.; SUBHASHINI. P.; LAKSHMINARAYAN. N. Anti-cancer activity of $\mathrm{ZnO}$ nanoparticles on MCF7 (breast cancer cell) and A549 (lung cancer cell). Asian Research Publishing Network Journal of Engineering and Applied Sciences, v. I0, p. 54I8-542I, 2015.

SILVA, L. F.; HOWER, J. C.; IZQUIERDO, M.; QUEROL, X. Complex nanominerals and ultrafine particles assemblages in phosphogypsum of the fertilizer industry and implications on human exposure. The Science of the Total Environment, v. 408, n. 2I, p. 5II7-5I22, 2010.

SILVA, L. F;; DABOIT, K.; SAMPAIO, C. H.; JASPER, A.; ANDRADE, M. L.; KOSTOVA, I. J.; WAANDERS, F. B.; HENKE, K. R.; HOWER, J. C. The occurrence of hazardous volatile elements and nanoparticles in Bulgarian coal fly ashes and the effect on human health exposure. The Science of the Total Environment, v. 4I6, p. 5I3-526, $2012 \mathrm{a}$.

SILVA, L. F; OLIVEIRA, M. L. S.; PHILIPPI, V.; SERRA, C.; DAI, S.; XUE, W.; CHEN, W.; O'KEEFE, J. M. K.; ROMANEK, C. S.; HOPPS, S. G.; HOWER, J. C. Geochemistry of carbon nanotube assemblages in coal soot, Ruth Mullins fire, Perry County, Kentucky. International Journal of Coal Geology, v. 94, p. 206-13, 20 I 2b.

SØRENSEN, G.; NIELSEN, A. L.; POULSEN, S.; NISSEN, M.; NYGAARD, S. Controlled release of biocide from silica microparticles in wood paint. Progress of Organic Coatings, v. 68, n.4, p.299-306, 2010. 
STOEGER, T.; TAKENAKA, S.; FRANKENBERGER, B.; RITTER, B.; KARG, E.; MAIER, K.; SCHULZ, H.; SCHMID, O. Deducing in vivo toxicity of combustionderived nanoparticles from a cell-free oxidative potency assay and metabolic activation of organic compounds. Environmental Health Perspectives, v. II7, n. I, p. 5464, 2009.

TEMIZ, A.; ALFREDSEN, G.; YILDIZ, U. C.; ENGIN, D. G.; KOSE, G.; AKBAS, S.; YILDIZ, S. Leaching and decay resistance of alder and pine wood treated with copper based wood preservatives. Maderas. Ciencia y tecnologia, v. 16, n. I, p. 63-76, 2014.

TROJER, M. A.; NORDSTIERNA, L.; BERGEK, A.; BLANCKC, H.; HOLMBERG, K.; NYDÉN, M. Use of microcapsules as controlled release devices for coatings. Advances in Colloid and Interface Science, v. 222, p. 18-43, 2015.

UNITED STATES DEPARTMENT OF AGRICULTURE (USDA). Types of Wood Preservatives. Available at: https://www. fs.fed.us/t-d/pubs/htmlpubs/htm06772809/page02.htm. Accessed in: 27 August 2018.

U. S. ENVIRONMENTAL PROTECTION AGENCY (EPA). Registration Review Process. Available at: https:// www.epa.gov/pesticide-reevaluation/registration-reviewprocess. Accessed in: 10 May 2018.

VAN DE KUILEN, J. W. G. Service life modeling of timber structures. Materials and Structures, n. 40, n. I, p. I5II6I, 2007.

VENMALAR, D. Screening of Oils of Pongamia pinnata Linn., Jatropha curcas Linn. and Simarouba glauca D.C. for Developing Eco-Friendly Wood Preservatives. In: PANDEY, K.; RAMAKANTHA, V.; CHAUHAN, S.S.; KUMAR, A.A.N. Wood is Good. Springer, 2017. p. 26I-268.

VIDAL, J. M.; EVANGELISTA, W. V.; SILVA, J. C.; JANKOWSKY, I. P. Preservação de madeiras no Brasil: histórico, cenário atual e tendências. Ciência Florestal, v. 25, n. I, p. 25727I, 2015.

VINARDELL, M.; MITJANS, M. Antitumor activities of metal oxide nanoparticles. Nanomaterials, v. 5, n. 2, p. I004I02I, 2015.
WAHAB, R.; DWIVEDI, S.; UMAR, A.; SINGH, S.; HWANG, I. H.; SHIN, H. S., MUSARRAT, J.; AL-KHEDHAIRY, A. A.; KIM, Y. S. ZnO nanoparticles induce oxidative stress in Cloudman S9I melanoma cancer cells. Journal of Biomedical Nanotechnology, v. 9, n.3, p.44 I -449, 20 I 3a.

WAHAB, R.; KAUSHIK, N. K.; KAUSHIK, N.; CHOI, E. H.; UMAR, A.; DWIVEDI. S.; MUSARRAT, J.; AL-KHEDHAIRY, A. A. $\mathrm{ZnO}$ nanoparticles induces cell death in malignant human T98G gliomas, KB and non-malignant HEK cells. Journal of Biomedical Nanotechnology, v. 9, n.7, p.II8I-II89, 2013b.

WALDRON, L.; COOPER, P.; UNG, T (UNIVERSITY OF TORONTO). Modeling of wood preservative leaching in service. Available at: https://pdfs.semanticscholar. org/la28/6ce77e I8b30ecd66f9bb659a67280a909496.pdf. Accessed in: 24 February 2017.

WALDRON, K. J.; ROBINSON, N. J. How do bacterial cells ensure that metalloproteins get the correct metal? Nature Reviews Microbiology, v. 7, n. I, p. 25-35, 2009.

WEIR, E.; LAWLOR, A.; WHELAN, A.; REGAN, F. The use of nanoparticles in anti-microbial materials and their characterization. The Analyst, v. 133, n. 7, p. 835-845, 2008.

WEITZ, I. S.; MAOZ, M.; PANITZ, D.; EICHLER, S.; SEGAL, E. Combination of $\mathrm{CuO}$ nanoparticles and fluconazole: preparation, characterization, and antifungal activity against Candida albicans. Journal of Nanoparticle Research, v. I7, n. 8, p. 342, 2015.

WIBOWO, D.; ZHAO, C.; PETERS, B. C.; MIDDELBERG, A. P. J. Sustained Release of Fipronil Insecticide in Vitro and in Vivo from Biocompatible Silica Nanocapsules. Journal of Agricultural and Food Chemistry, v. 62, n.52, p. I2504|251।, 2014.

YU, Y.; JIANG, Z.; SONG, Y. Growth of ZnO nanofilms on wood with improved photostability. Holzforschung, v. 64, n.3, p. 385-390, 2010.

ZABEL, R. A.; MORRELL, J. J. Wood Microbiology: Decay and Its Prevention. Academic Press, 2012. 498 p. 